\title{
Interaction as a Central Element of Co-Creative Wine Tourism Experiences-Evidence from Bairrada, a Portuguese Wine-Producing Region
}

\author{
Mariana Carvalho *, Elisabeth Kastenholz and Maria João Carneiro
}

Citation: Carvalho, M.; Kastenholz,

E.; Carneiro, M.J. Interaction as a

Central Element of Co-Creative Wine

Tourism Experiences-Evidence from Bairrada, a Portuguese

Wine-Producing Region.

Sustainability 2021, 13, 9374. https://

doi.org/10.3390/su13169374

Academic Editor: Alan Fyall

Received: 15 July 2021

Accepted: 14 August 2021

Published: 20 August 2021

Publisher's Note: MDPI stays neutral with regard to jurisdictional claims in published maps and institutional affiliations.

Copyright: (c) 2021 by the authors. Licensee MDPI, Basel, Switzerland. This article is an open access article distributed under the terms and conditions of the Creative Commons Attribution (CC BY) license (https:/ / creativecommons.org/licenses/by/ $4.0 /)$.
GOVCOPP Research Unit, Campus Universitário de Santiago, University of Aveiro, 3810-193 Aveiro, Portugal; elisabethk@ua.pt (E.K.); mjcarneiro@ua.pt (M.J.C.)

* Correspondence: marianacabralc@gmail.com

\begin{abstract}
Wine tourism experiences promote not only rural territories' distinctive wine and food products, but also their local identity, natural and cultural resources and historical features that add value and uniqueness to tourist experiences. The new experience paradigm applied to tourism invites stakeholders to rethink how and why tourists travel and live their experiences on holidays. Interaction and engagement are components of co-creation, stressing the central role of visitors sharing value creation with other destination stakeholders. The present qualitative study uses discourses from 22 semi-structured in-depth interviews with visitors to Portugal's Bairrada wine region. Content analysis, carried out with QRS Nvivo 12, shows that interaction enhances wine and food experiences in several contexts. Storytelling seems to contribute to value creation, with stories co-created between winemakers or other destination stakeholders and visitors. Apart from this social interaction, visitors' physical interaction with natural and cultural destination features is also revealed as a crucial part of wine tourism experiences. Study results suggest the importance of DMOs, facilitating co-creation experiences in wine regions, contributing to visitor satisfaction and loyalty.
\end{abstract}

Keywords: rural wine tourism; co-creation; tourist experience; interaction; wine region; Bairrada

\section{Introduction}

A literature review on wine tourism shows an increasing academic focus on this topic since the mid-90s, encompassing diverse empirical studies that reflect the complexity of this tourism product [1-7]. Distinct developments in wine tourism are also observable around the world, with the so-called 'old world' wine producing countries, mainly in Europe, focusing more on wine and its production, while 'new world' wine producing countries (e.g., South Africa, USA, Australia) tend to present a wider variety of recreational and holistic tourism experiences in the wine tourism context [8].

However, the literature review clearly shows that more research is needed to discuss and clarify the nature of the wine tourism experience in wine cellars and wine destinations $[1,6,9]$.

Wine tourism is frequently associated with rural areas and agriculture; it is becoming a vital part of the economic vitality of these territories $[5,10,11]$. The potential of local wine production may also be enhanced through wine tourism experiences, helping to reveal the region's wine quality and various varieties, stimulate wine and tourism business and employment, attract new investment and contribute to the region's tourism appeal and overall development [4,5]. In this context, the concept of terroir is paramount. It refers to the features of the wine-producing rural territory that influence the quality of wines and their distinctiveness, namely 'topography', 'climate', geology' and 'soil' [7] (p. 2). Terroir is also associated with the particular cultural landscape designed through wine production, and it has been acknowledged as an essential motivation for visiting wine regions [12]. 
Wine tourism experiences are frequently "a part or enhancement of (any kind of) holiday experience" in wine-producing regions [2] (p. 252). Tourists' motivation to visit wineries and wine cellars is mostly associated with wine tasting. The wine itself is the central product of wine tourism experiences, and in addition to specific terroir characteristics, it is frequently perceived as a distinctive asset that may contribute to a rich sensory experience, where all senses (taste, smell, hearing, touch and sight) are stimulated [1,2,5,7]. However, other destination attributes are also included in these experiences. An integrative tourism experience, particularly in rural areas, encompasses local natural and cultural resources as crucial elements that contribute to unique, sensory-rich and emotion-generating experiences that eventually lead to place attachment [13]. The strengthening of historical and cultural elements and the preservation of local culture and culinary practices, as well as the landscape and the quality of wines, are also included in wine tourism $[1,6,14,15]$. This perspective has been adopted in this exploratory study, since a holistic tourism approach contributes to the deeper meaning of experiences. Wine production is part of a territory's identity, and wineries that are open to visitors may enhance their brand image and foster demand amongst markets that seek uniqueness and authenticity $[2,4,6]$.

Tourists increasingly look for more intense involvement in place experiences while travelling; they want to learn something different, explore new places and live unique, memorable experiences [16,17]. These market developments suggest that a new paradigm of tourism experience enhancement should be implemented in order to meet tourists' expectations and foster the competitiveness of the tourism product [16-18]. In this context, a trend towards co-creation is emerging, where co-production of the experience involves co-creating value together with other actors, such as local businesses, organizations and the community $[17,19,20]$. Tourists want to be part of the destination and have an active role and the opportunity to engage in meaningful interaction with locals $[15,20]$. Hence, co-creation opportunities may be perceived as strategically enhancing wine tourism experiences and destination attractivity.

Despite the increasing relevance and interest in literature regarding wine and food experiences, little is known about how co-creation and its dimensions relate to specific experiences in wine destinations [21]. This paper analyses the importance of visitors interaction with others and the environment, as one of the key dimensions of tourism co-creation, in promoting visitors' value creation in wine and food experiences in the Bairrada wine region. Through an in-depth analysis of discourses, a holistic perspective of the tourist experience is found, enabling the comprehension of reflections and evaluations regarding the destination environment, natural and cultural resources and attractions, local food and wine and other local features experienced by visitors to a Portuguese wine region. These experience discourses go beyond visits to wine cellars and wine tasting experiences. This empirical study is part of a scientific project (see Funding section) that studies co-creative wine tourism experiences in three rural wine regions located in Central Portugal, focusing here on the Bairrada region.

Results show the role of co-creation as a key to enriching wine tourism experiences, especially in rural areas without important flagship attraction [22], but where diverse natural and cultural resources may together add a globally unique and appealing destination experience $[15,23])$.

This paper first presents a theoretical reflection on wine and food tourism experiences in rural areas and co-creation in tourism, particularly focusing on visitors' interactions with others and the physical environment. The methodology adopted to carry out this empirical study is explained, followed by a presentation and discussion of results. Conclusions and limitations of the study, specifically for improved tourism marketing of rural wine destinations, are also presented. 


\section{Conceptual Background}

\subsection{Wine Tourism Experiences}

Wine tourism may be defined as "visitation to vineyards, wineries, wine festivals and wine shows, for which grape wine tasting and/or experiencing the attributes of a grape wine region are the prime motivating factors for visitors" [1] (p. 3). For Carmichael [5] (p. 185), wine tourism is defined according to "different geographical scales [ ... ] involving visitor perceptions of physical landscapes and built environment, as well as human interactions". For Getz and Brown [6] (p. 147), "wine tourism is, simultaneously, a form of consumer behavior, a strategy by which destinations develop and market wine-related attractions and imagery, and a marketing opportunity for wineries to educate, and to sell their products, directly to consumers." These three different perspectives stress not only wine as the primary motive to travel to these destinations, but also the importance of the destination's environment, namely the experiencescape and its diverse resources, while also underlining the importance of wine tourism to a region's positioning and differentiation.

Besides the experience of the wine as a product and local culture and lifestyles, the landscape and local resources are also part of this sensorially enriched experience [1,11,24]. As a quality product totally associated with wine, local gastronomy and traditional culinary practices are also relevant and contribute to reinforcing the authenticity and uniqueness of the experience $[3,25,26]$. Gastronomy adds value to the experience and is recognized as meeting many more than just the biological needs of individuals while travelling. Even when it is not the primary motivation, gastronomy is a distinctive factor of an experience, contributing to its memorability. Gastronomic experiences foster social interaction, allowing visitors to better perceive local culture and traditions in an informal context, which is highly appreciated by visitors $[13,25,27]$.

Wine tourism currently takes several forms, namely wine festivals, wine-related workshops, cellar and winery visits, wine tasting, winery tours, food and wine pairing, visits to wine routes and observing the harvesting process [3]. Other less used winery experiences are also emerging, such as helicopter rides, ballooning, music events and activities for children, like facial painting [28] and other family-friendly activities [29]. Gift shops, restaurants, cafés and hosting events like weddings are also services that can be found in wine regions [28]. As pointed out by Dodd [10], wine is related to relaxation, social interaction, hospitality and learning new things, which are clearly promoted in the experiences previously referred to, raising tourists' involvement and bringing greater economic benefits for destinations [3,6,10,23,30,31]. Quadri-Felitti and Fiore [31] consider that the educational experience dimension is crucial to promote visitors' involvement in the experience, adding value, creating memories and enhancing loyalty. Dodd [10] (p. 8) stresses the importance of "creating awareness and knowledge" to increase tourists' interest in local wine, which might also benefit supply agents in their wine sales and promotional efforts.

Empirical studies that reflect on wine tourists' profile contribute to understanding their expectations and needs, which is crucial to wine producers and managers trying to deliver valuable experiences. According to Hall et al. [23] (p. 6), "the motivations, perceptions, previous experiences and expectations of the wine tourist" are part of what should be perceived in tourism demands to better predict tourists' behaviour. Wine tourists are interested in enjoying wine tasting and buying wines while on holiday, but the experience involves more than this [2]. They enjoy learning about the production process, grape varieties and terroir characteristics, having the opportunity to socialize and interact with local producers and local agents, enjoying the natural and rural landscape and visiting other destination attractions $[2,3,5,10,23,32-34]$. However, wine tourists show differences regarding levels of interest in and previous knowledge about wine, which influence the experience [2]. Hall [35] suggests that wine tourists may be divided into three segments: 'wine lovers', 'wine interested' and 'wine curious'. 'Wine lovers' have a strong interest in wine and its production process, travel specifically to visit a winery, are educated and preferably buy wine from local producers and wineries. They are knowledgeable, 
want to learn more and have a critical perspective about wine, based on their previous experiences [3,32]. 'Wine interested' tourists are also fond of wine but have less expertise in the wine making process; they are also educated and tend to buy wine at wineries. 'Wine curious' tourists appreciate wine, but they know little about the wine production process: wine is not their primary motivation for travelling. On average, they have moderate education and may buy wine from local producers or not. However, apart from these tourists with diverse levels of wine interest and involvement, there are also tourists who visit wine regions and may not be interested in wine tasting, as they are non-wine drinkers who are attracted to wine regions due to other motivations, such as visiting rural areas, enjoying the landscape or heritage and cultural resources [5] or as a family vacation activity [29]. All this reinforces the need for deeper understanding of the diverse profiles, desires and behaviors of those visiting wine regions [24].

The "winescape" comprises several natural and cultural elements that are the essence of this typical landscape. Winescape encompasses the wines, the vineyards, wine production, the wineries and infrastructure, the natural landscape, staff, heritage, artefacts and architecture [36]. The aesthetic dimension of the experience is most important in the holistic tourism experience $[2,18]$; the visually remarkable landscape with its cultural peculiarities and natural resources are key components [11]. Typical wine landscape features seem to be attractive, with the vineyards' design being of particular aesthetical appeal [3,35]. As an experience dimension pointed out by Pine and Gilmore [18], 'aesthetics' suggests the tourists' immersion in experiencescapes, where they enter the landscape while assuming a rather passive contemplative role. This aesthetic enjoyment of the winescape, with its diverse and characteristic natural and cultural resources, is a very relevant aspect of the wine tourism experience, adding value and contributing to its uniqueness and memorability.

\subsection{Tourism Co-Creation and Co-Creative Wine and Food Tourism Experiences}

Co-creation is part of a recent concept within tourism development models, related to Pine and Gilmore's [18] experience economy paradigm. The authors highlight that promoting experiences, instead of delivering services, would give tourists opportunities to get involved and thus create memorable moments in life. The authors suggest a 4Es model that comprises experience realms identified as entertainment, education, aesthetics and escapism, where tourists may assume an active or passive participation and feel immersed or absorbed in the experience [18]. They also suggest that the ideal, richest possible experience, called a "sweet spot", comprises the four realms. Focusing on the key role of customers in the tourism experience suggests perceiving them as co-producers of their own experiences $[16,17,20,37]$. This perspective implies interaction and shared value-creation, which leads to the concept of co-creation. This notion was first proposed by Prahalad and Ramaswamy [38], who consider that value creation emerges from the interaction between companies and consumers. Minkiewicz, Evans and Bridson [39] (p. 31) explain that "co-creation involves an effort between multiple stakeholders to cocreate value/an experience collaboratively". Hence, it stimulates human interaction and provides the ideal context for consumer engagement in personalized experiences provided by enterprises [17,38,39]. Prahalad and Ramaswamy [38] also reinforce that high-quality interactions in co-creative experiences contribute to a competitive advantage. As noted in the literature, value co-creation comprises operant and operand resources as they contribute to visitors' involvement and satisfactory experiences [40,41]. As intangible and dynamic, operant resources correspond to the visitors' knowledge, skills and know-how, and these are facilitated by social interaction, where the dialog between different actors stimulates shared value-creation [29,41-43]. Operand resources, which correspond to the physical context, local resources and the setting, are also crucial to promoting immersive and meaningful experiences [41,42]. Involving customers in active participation leads to engaging and more meaningful experiences, in which customers are co-producers and co-creators of value $[17,40,44,45]$. Value creation in tourism is fostered when tourists have close contact with local communities, local agents and destination resources, promoting authentic, 
unique and memorable experiences $[17,40]$. As an active agent, tourists' involvement is crucial in experience design $[40,46]$.

Co-creation dimensions are presented by different authors who suggest that tourists assume an active participation, engage in human and physical interaction $[17,39,47]$, marked by psychological, cognitive and emotional engagement $[1,39,41,46]$. These components of co-creation suggest dimensions that should be developed in tourism experiences, when aiming at sensory rich, meaningful and stimulating immersion in enjoyable destination contexts [1,17]. In this study, the perspective of Campos et al. [17] has been adopted, who define co-creation as "the sum of the psychological events a tourist goes through when contributing actively, through physical and/or mental participation, in activities and interacting with other subjects in the experience environment" [17] (p. 3).

One should assume that tourists seek engaging and immersive experiences, trying to experience something unique and memorable, to have close contact with local producers and connect to the territory's identity. Traditional visits to wineries, cellars and wine tasting are crucial in wine tourism, but there is a need to foster other genuine elements to improve and differentiate the experience $[4,6,9,24]$. Wine and food experiences in rural territories should therefore meet and, if possible, exceed tourists' expectations by promoting personalized experiences that engage personal resources (such as previous knowledge or experience), thus contributing to visitors' engagement and satisfaction [17,34,48].

The analysis of co-creation in wine experiences is still rare in the tourism literature, confirming the relevance of this exploratory study. The following subsection presents the specific features of this experience dimension.

\subsection{Interaction and Its Relevance in Wine Tourism Experiences}

In co-creative tourism experiences, interaction has a relevant role, and several studies have pointed out that active participation and interaction with others and the environment are frequently associated with more positive and memorable experiences [17,37-40,46-50]. Interaction is also associated with engagement in the tourism experience, which can be perceived "as a psychological state incurred by interactive, co-creative, tourist experiences with a focal agent/object (people/attraction/activities/ encounters) in focal travel experience relationships" [47] (p. 6). Interaction also fosters self-expression, learning and creativity $[16,20]$.

Tourists' interaction on-site may be fostered in destinations' human (several actors) and physical (natural and cultural resources) environment, resulting in increased value for all those involved $[40,47,48]$. As part of co-creation, social interaction implies visitors' contact with destinations' stakeholders, such as supply agents, the local community, other tourists or a travel group, sharing ideas, feelings and personal perceptions [21,45,47,49]. Wei et al. [50] (p. 467) found that interaction between tourists and a local community contributes to "high-level experiential feelings, such as a sense of happiness, warmth and belonging, as well as social connection with local residents". Kastenholz, Carneiro and Eusébio [51] identified the positive consequences of social interaction for visitors to rural areas, suggesting that "those who interact, both with fellow tourists and with residents, report a richer and overall more pleasant experience, including more activities undertaken, learning opportunities, sensations and emotions enjoyed" (p. 417).

In wine tourism, human interaction is frequently central to guided wine tours and tasting experiences, in which tourists can learn about the wine production process or about cultural and historical features that influence regional grape varieties, as well as wine producers' business decisions. Bruwer and Alant [2] refer to people engagement as a natural part of these experiences, where interaction may intensify tourists' cognitive, emotional and social experience dimensions [47].

According to Dodd [10], interaction may use storytelling, contributing to more engaging experiences and loyalty development. Every winery has its own features and history, involving not only differences in wine production, wine blending or winescape, but also the history of family ancestors that funded the wineries in the past and whose heritage 
is still preserved $[33,52]$. These distinctive elements contribute to visitors' perception of authenticity, as well as to the uniqueness of the experience. Storytelling thereby promotes value creation, especially if given by an empathetic local guide, wine producer or enologist able to react to visitors' questions. The visitors themselves may add to the story. As Jolliffe and Piboonrungroj explain [53] (p. 227), "[storytelling] provides a framework for hosting the visitor's experience", in the sense that it facilitates visitors' interaction with local hosts, providing them the chance to be co-creators of their tourism experience. Storytelling recovers and enhances historical features that may be preserved through tourism and contributes to stimulating visitors' imagination, involving them cognitively and emotionally, fostering immersive experiences [54]. Although storytelling has already been analyzed in several tourist contexts [54-57], its importance in wine tourism experiences seems to be underrepresented in academic literature [33]. The interaction between staff and visitors in wine cellars is of particular importance in the wine tourism experience, even though other contexts may foster storytelling opportunities.

Interaction with the destination's physical environment is also relevant in the tourism experience as it influences tourists' involvement and the quality of social interaction in experience co-creation $[40,58]$. Interaction with physical winescapes, shaped by unique local resources, may also contribute to more genuine and memorable experiences [36].

\section{Materials and Methods}

\subsection{Rota da Bairrada}

In Portugal's Central Region, Rota da Bairrada corresponds to a wine region with native varieties and terroir specificities that contribute to high quality and differentiated wine products, recognized world-wide. Its natural sparkling wine is part of the region's brand image and contributes to a unique wine tasting experience, which is frequently paired with another traditional and nationally highly valued regional food specialty which attracts visitors to the region: 'Leitão da Bairrada' (traditional suckling pig cooked in a stone oven). Geographically, the region encompasses eight municipalities, namely Mealhada, Anadia, Águeda, Oliveira do Bairro, Aveiro, Vagos, Cantanhede and Coimbra [59]. The region has 164 accommodation units, mostly located in Anadia, Aveiro, Mealhada and Coimbra [60]. Data from 2019 shows that there were approximately 3000 overnight stays per 100 inhabitants [61] in the eight municipalities, with the highest demand registered in the aforementioned municipalities. In 2019, the average stay in the region was 1.9 overnights, with international tourists staying 2.31 nights, compared with domestic tourists staying 1.65 nights [62].

The Bairrada region has diverse natural and cultural attractions appealing to an eclectic tourist demand. As a coastal territory, Bairrada also offers sun and sea tourist products. Two very relevant Portuguese urban destinations and university centers are located here, namely the coastal city of Aveiro and Coimbra. The nationally well-known thermal spas of Curia and Luso are also important attractions. Nature tourism is also prominent in the region: the protected area of Mata do Buçaco (Buçaco Woods) stands out, an abundant forest planted by medieval monks with over 400 native species of the Portuguese Atlantic range [63]. With strong historical features, Palácio do Buçaco and Hotel-Palácio da Curia are two iconic accommodation units.

The Rota da Bairrada Association was created in 2006 with the aim to promote local wine production and its branding while also stimulating a wider terroir tourism experience, integrating the region's cultural and natural resources. This non-profit organization includes several types of public and private sector stakeholders, such as 38 wine producers, territorial planning and development agents and agents of regional tourism supply (e.g., 18 local accommodation units and 25 restaurants) [59,62].

\subsection{Data Collection and Analysis}

Lengthy in depth semi-structured interviews were used, structured according to a literature review on wine and food tourism experience and on co-creation, to understand 
visitors' motives and experience expectations regarding wine tourism and visitor experiences while travelling around the Bairrada region, particularly focusing on the nature and role of visitors' interaction with human and physical experiencescapes. As a qualitative tool, semi-structured interviews embrace open-ended questions that allow participants to express themselves without pre-defined or expected answers [64], as opposed to short closed-ended interviews in quantitative studies [65]. The script for the interviews was reviewed by researchers from the TWinE project and also by experts in the field of wine tourism. Within the scope of the TWinE project, a comprehensive analysis of the wine experience was considered essential for expanding wine experiences beyond the traditional visits to wine cellars. The interview was divided into three parts (Appendix A): the first acknowledged visitors' wine experience expectations; the second inquired about visitors' experiences in Bairrada, in terms of motivations, and the most typical elements in the region, the sensory experience, the activities that were part of those experiences and the quality of their interaction with the destination's stakeholders, the travel group and other tourists. The third section characterized the visitors' profile. A convenience sample was used, encompassing visitors who were present in the region for leisure, holidays or visiting family and friends, on certain days and in diverse seasons of the year, either travelling on a one-day trip or taking an overnight stay. A total of 22 visitors were interviewed, individually or in a group (max. 3), face-to-face, in the places they were visiting or staying. According to the academic literature on qualitative study designs, sample sizes between 1 and 20 [66] or 5 and 25 [67] were considered appropriate, due to the fact that "the validity, meaningfulness and insights generated from qualitative inquiry have more to do with information richness of the cases selected and the observational/analytical capabilities of the researcher than with the size of the sample" [68] (p. 245). Accordingly, the size of our sample is considered reasonable, uncovering rich detail on diverse tourist experiences in the region. The purpose was to gain an in-depth understanding of the phenomenon under study $[64,66]$ and to reveal participants' perceptions and opinions about the topics in focus [69].

Before holding the interviews, local agents along the Bairrada wine route were identified, and permission was asked (and obtained) to hold the interviews in their premises, which allowed the researchers to contact individual tourists. Data were collected between May 2019 and February 2020. During this time period, interviews were held out of holiday seasons, except for the Carnival holidays (in February 2020), when the final five visitors were interviewed. No more interviews were carried out after this period, due to the Covid-19 pandemic and the subsequent lockdown periods and lack of tourists at the destination. The interviews took place in the following places: in the official store of the Rota da Bairrada Association; in the local winery Luís Pato; in the rural accommodation unit Quinta de São Lourenço and in the Hotel da Curia. The diverse origins of visitors required that the interviews were held in Portuguese and in English. All interviews were recorded, with visitors' permission, and later transcribed. The average length of the interviews was 35 minutes. There were 14 overnight tourists and eight day visitors. The content analysis of these in-depth semi-structured interviews was undertaken with the support of software QRS Nvivo 12. All discourses were categorized and codified for further analysis.

\section{Results}

\subsection{Co-Creative Wine, Natural and Cultural Tourism Experiences in Bairrada}

According to Table 1, depicting the sample profile, all the interviewees were visiting the destination for leisure $(\mathrm{N}=4)$ and holiday purposes $(\mathrm{N}=18)$, with most being overnight tourists $(\mathrm{N}=14)$, while a smaller amount were day visitors $(\mathrm{N}=8)$. Most visitors were employed $(\mathrm{N}=19)$ and had a higher education degree $(\mathrm{N}=16)$. Female visitors $(\mathrm{N}=15)$ predominated in the sample, and the visitors' age range was from 29 to 70 years. Three age groups were identified, namely 29-44 $(\mathrm{N}=8), 45-60(\mathrm{~N}=10)$ and above 60 $(\mathrm{N}=4)$, out of which 29-44 and 45-60 years-old were the most prevalent. Most participants were travelling with family and friends $(\mathrm{N}=21)$. The sample comprised more foreign 
visitors $(\mathrm{N}=15)$ than domestic travelers. Regarding international visitors, their country of residence was quite varied, including United States of America $(\mathrm{N}=3)$, Switzerland $(\mathrm{N}=3)$, France $(\mathrm{N}=3)$, Belgium $(\mathrm{N}=2)$, Lithuania $(\mathrm{N}=2)$, Brazil $(\mathrm{N}=1)$ and Germany $(\mathrm{N}=1)$. The other visitors were living in Portugal $(\mathrm{N}=7)$.

Table 1. Characteristics of the sample profile.

\begin{tabular}{lccccccc}
\hline \multicolumn{2}{c}{ Residence } & \multicolumn{2}{c}{ Visitor } & \multicolumn{2}{c}{ Travel Group } & \multicolumn{2}{c}{ Gender } \\
\hline Portugal & 7 & Tourist & 14 & $\begin{array}{c}\text { Family } \\
\text { and } \\
\text { friends }\end{array}$ & 21 & Female & 15 \\
Foreign & 15 & Excursionist & 8 & Individual & 1 & Male & 7 \\
\hline
\end{tabular}

Concerning the experiences sought and lived by visitors in the Bairrada region, two segments stood out: the first one $(\mathrm{N}=9)$ included visitors who experienced food and wine pairing, wine tasting and harvesting. They showed interest in having close contact with this regional product, while also enjoying other cultural and natural attractions in the region. The second segment $(\mathrm{N}=13)$ comprised visitors who were not primarily motivated to experience wine in Bairrada, but instead came to the region to relax and for cycling $(\mathrm{N}=8)$, hiking $(\mathrm{N}=2)$, enjoying thermal and spa treatments $(\mathrm{N}=2)$ or learning something new in a pruning workshop $(\mathrm{N}=1)$. Visitors from this second group were wine drinkers that had occasionally the opportunity to taste local wine during meals but also non-wine drinkers $(\mathrm{N}=3)$, who were actually seeking other place experiences.

Still, as an important motivation for visiting the Bairrada region, many respondents referred to their interest in wine tasting and in getting to know distinctive features associated with this product, as well as its production and regional context:

"They are usually regions that in themselves have certain characteristics associated with a certain context, with a certain history, most often associated with wine production itself, but they are also areas with [ ... ] a certain way of being that distinguishes [them] from other regions."

(V5_Female, 34 years old)

"We really like to participate in the experience and see where the wine is produced, where the grapes are harvested, the transformation process and have contact with the local community for a more wine-guided history."

(V16_Male, 35 years old)

However, when wine is not part of the travel motivation, other features stand out, as this visitor states:

"[I'm motivated by] the context, the contact with nature, the peace, the opportunity to do things different from usual... not exactly because of the wine."

(V30_Female, 33 years old)

Some visitors, who tend to travel to wine regions for other motivations also mentioned that wine usually "comes as a very good addition".

(V20_Female, 47 years old)

When visiting wine regions, visitors expect to do different things, such as tasting good wine and food, understanding the terroir, learning new things, escaping from routine, enjoying the natural (quiet and calm of rural areas) and cultural environment, experiencing a wine route with the possibility of getting to know different wineries, experiencing the authenticity of the region or even getting to know historical features related to wine:

"The history of the wine and food and explanation of how they make it and the romance, you know, behind."

(V13_Male, 56 years old) 
"Wine encompasses a lot more than the drink itself. When you hear about the history behind the brand, you start to appreciate it even more. That's really interesting to me."

(V16_Male, 35 years old)

As mentioned by one of the visitors, interaction with destination stakeholders contributes to destinations' uniqueness, which is highly appreciated when tourists travel to wine regions:

“( ... ) the sharing of information... I think this is what makes the difference between a wine tasting in a generalized context and in a specific region where there is always a unique impression and a brand associated with the region."

(V5_Female, 34 years old)

Furthermore, visits to wineries, wine tasting, wine and food pairing and harvesting were highlighted. One of the visitors reflected on how special the wine and food pairing experience was, referring to unique moments in which one is closer to the origin of the product and its production traditions and place:

"What is really interesting is when we go to a winery, it's a farm, it's agriculture, and so we don't think about this when drinking at home for dinner. So, that's like the combination of going to a farm and then having this wine tasting experience and amazing food, all that stuff coming together is really interesting."

(V14_Female, 54 years old)

Visitors who preferably chose the region for other, non-wine-related reasons mentioned hiking in nature, cycling in the region, a pruning workshop and spa and thermal treatments, since Bairrada is also known for its historical thermal spas, Termas da Curia, and the nationally renowned Luso waters.

When asked about what they considered the most typical in the region, an interesting aspect mentioned by visitors was hospitality. From foreign visitors' perspectives, mainly for those who were cycling, the frequent greeting by local people was a very positive surprise:

[Local people are] "also very genuine, because in Belgium, if you walk or make a bicycle tour it happens that nobody says 'hi!' ... [I was] surprised and here everybody says 'Bom dia', 'Boa tarde', everybody!'

(V21_Male, 48 years old)

Other visitors, who live in Portugal, corroborated this perspective:

"People from Bairrada are friendly and welcoming, this is also very touching for us in Bairrada."

(V16_Male, 35 years old)

The wine and wine culture, as well as the contact with nature, the landscape, the rural settings and the several related opportunities that tourists are offered to enjoy were also pointed out. The distinctive regional wine features, namely grape specificities and varieties, were recognized as crucial to add value to the wine experience:

"Baga [a regional grape variety] makes a distinction, there are many characteristics of the region that mark [ ... ] and this is really valuable."

(V5_Female, 34 years old)

Stressing this singular quality of the wine, visitors suggest it should contribute to the region's differentiation and be especially highlighted in the Portuguese context:

"The wine from Bairrada is not a wine for mass consumption and has to be sold as such."

(V5_Female, 34 years old) 
Regarding gastronomy, visitors really appreciated local food and consider that through culinary practices, they are in contact with cultural features and local identity:

"All the wonderful food and the traditional food and the combination of things

... I really enjoyed having a full understanding of what local food is."

(V13_Male, 56 years old)

From the visitors' perspective, the most typical features of the region refer to local gastronomy, with traditional dishes like codfish, chanfana (old goat) and suckling pig, as well as regional pastries, particularly, ovos moles ('soft eggs', a sugar-rich traditional convent-originated sweet, based on the yellow of the egg) and almond jam, all standing out. As an important attribute of the place experience, visitors consider that gastronomy adds value and authenticity to their experiences, also marked by the atmosphere of small cafés and the architecture and decoration of the buildings where this food is eaten.

According to the participants' viewpoint, senses were also stimulated by their experiences. As visually appealing features, buildings stood out, namely the "beautiful houses" (V6), the beauty of the Hotel da Curia, especially at night with its illumination, the natural environment and specific natural elements, such as rose bushes, lots of trees and the wine landscape, materialized in the vineyards, such as "vines of strawberry plants and vines in a row" (V5).

The visual experience was also enhanced in a wine and food pairing experience, as visitors highlighted as visually attractive "the way that the table looks and the people" (V13). In a less positive perspective, some visitors mentioned the lack of human presence in the streets or some signs of lack of cleanliness in public spaces.

As for smells, the wine and wine-related fragrances were mentioned, such as grape fermentation (called mosto) and the associated cellar smell that for one visitor recalled a sense of nostalgia from childhood memories. Furthermore, the smell of arinto (a grape variety) was referred to, apart from nature-related smells, specifically the eucalyptus trees in the forests.

Nature continues to stand out in terms of sounds, with visitors stressing the sound of birds, frogs, ducks, dogs and the wind in the forest, as well as sounds related to a more rural living context, like the church bell, considered "very special" (V7), or even the silence and quietness of the ambience. The sound of the cork coming out of the bottle was also mentioned.

As for flavors, regional food (piglet) or local pastries are recalled, such as the case of bairradino (whose ingredients are local sparkling wine, almond, eggs and sugar), fruits, coffee, sparkling wine (a typical wine of the region), wine varieties like baga and bical (typical red and white wine grapes varieties from the region), sometimes connected to the highly appreciated well-arranged combination of flavors in food and wine pairing.

Touch is less perceived by visitors, being perhaps a less consciously assessed sensorial dimension, with some not mentioning any element, while others refer to the touching of the glass, a rough touch of dry land, touching grapes or hard branches, resulting from the pruning workshop.

\subsection{Interaction with the Physical Environment}

The interaction with the physical destination environment or experiencescape was particularly strong for visitors motivated by cycling. The results show that, generally, tourists did not search for detailed information about the region before travelling, but their main aim was to enjoy the region through the natural contact they had during their holidays, getting physically immersed in a landscape whose natural features and aesthetic beauty were most appreciated, as illustrated in the following statement:

"The surprise when you arrive with your bike, enter the gate and then you see this [pointing at the beautiful garden of the rural accommodation unit] from this place, for example, you enter the door, and there's such a paradise garden, it was everywhere like this." 
(V8_Female, 61 years old)

Another visitor highlighted how delightful it was to enjoy different seasonal landscapes in the region:

“There are very specific vineyards, that vineyard that runs on a very gentle hill ... Then in autumn, you get some funny colors, then it's cute, because of the different varieties ... The leaves start to change at different times. So... going by the region in October, you can delight yourself with the colors ... some are already yellow, others are still green ..."

(V5_Female, 34 years old)

One of the visitors referred to how important the contact with the land was and how the harvesting experience influenced her reflective perspective on this practice:

“The moment I was there ... it's something that isn't that fast [ . . . ] it's a personal experience that is real ... and the difference is the fact that you are experiencing an ancient tradition [ ... ] and suddenly you see yourself being part of the wine production process, not from a touristic perspective but like the locals do, working beside them. For me, it was a reflexive moment."

(V18_Female, 32 years old)

In fact, many reports reveal a globally immersive experience, involving interaction with both human and physical context, while making people reflect on the 'real life' encountered at a distinct place, enhancing personal connections to that place and its people.

\subsection{Interaction with the Human Experiencescape}

Interaction is one of the co-creative experience dimensions that stood out according to visitors' experience reports, who referred to interaction with local agents, producers, staff or local guides as highly contributing to their overall satisfaction. One of the visitors recalled how important interaction was in her harvesting experience involvement:

"Today, in the experience of harvesting I had the opportunity to meet a man in his 70s who works here since he was a young boy ... you know, getting to know the people... I think this is important."

(V17_Female, 34 years old)

This visitor also confirmed the engaging nature of the experience she was part of, mainly due to the genuine interaction that contributed, in a certain way, to self-development:

"A moment of personal reflection [ ... ] more than a wine tasting in which you are always with people ... it is surprising from the point of view of being different and for not being very touristy [ ... ] being together with the staff, we had lunch with them, so there was nothing created for us [as tourists], on the contrary, so it was interesting due to that [opportunity]."

(V18_Female, 32 years old)

In the same experience, another visitor referred to the locals' genuine warmth and friendliness during the harvesting as well as the natural and easy interaction with them that was also clearly fostered:

"People are simple, but extremely welcoming ... they want visitors to be always very comfortable and want to help and offer something [ ... ] people are very simple, communication is very simple, too."

(V16_Male, 35 years old)

"One thing that we like and that we have noticed is the exchange of experiences, they [staff] ask where we come from, what we do and we always have that 
mutual interest of wanting to know how it started, what they do besides this ... well, the harvest is only a short time, and the rest of the year what do they do, what are the plans, the dreams ... [ ... ] this contact has always been very interesting."

(V18_32 years old)

Regarding visitors' interaction with local community or local agents, visitors generally refer to a very positive pattern. The interaction resulting from the contact between wineries' local staff and visitors led them to characterize agents as "down-to-earth" (V15_Female, 49 years old), "authentic, proud" (V14_Female, 54 years old) and "professional, they are excellent" (V13_Male, 56 years old). Visitors, mainly foreign visitors who were in Bairrada for cycling, highlighted locals' hospitality and friendliness. Referring to the local community, they said: "We always hear: 'Bom dia [Good morning]!!'” (V6_Female, 61 years old), "They are so nice" (V7_Female, 56 years old), "The people are very, very friendly and kind." (V6_Female, 61 years old) and "Locals are friendly, always 'Bom dia, Bom dia, Bom dia' [Good morning] and [ ... ] they are polite" (V19_Female, 49 years old).

Foreign visitors refer to the language barrier, mainly regarding comprehension issues identified in some interactions with the local community or staff. However, locals' kindness in this context was highlighted:

"I was surprised, almost nobody speaks English so we can't really talk, but everybody is so friendly and open."

(V8_Female, 61 years old)

For some of them, the social interaction within the travel group was the best part of the travel experience:

“That's a highlight, of course, travelling with my friends ... it's the highest highlight."

(V8_Female, 61 years old)

One of the visitors even reinforced that interaction, recalling that a wine experience lived in Bairrada was something that became memorable and resulted from the combination of tasting wine and interacting with other (unknown) tourists. The visitor stated that

"The first time we were here [in the official store of Bairrada route association] on a wine tasting with three other people we had never been with, the store closed and we ended up outside, at a picnic table, sitting with three gentlemen we didn't know before, drinking a bottle of sparkling wine and talking about things ... (laughs). We will never see them again, in fact, but it was an experience that stayed in our memories [ ... ] When I talk about this experience, I say 'it was really cool' and I think that's what people are increasingly looking for, something that is a different experience."

(V5_Female, 34 years old)

This visitor even considers that the Bairrada region should be promoted for the quality of hospitality and the human interaction that is genuine and a distinctive element that meets tourists' expectations in wine and food experiences:

"[about the region's marketing] the region has to be distinguished for its human component, in a globalized society [ ... ] it makes a difference."

(V5_34 years old)

This idea was reinforced by another visitor who considered that "people are undoubtedly a reference and a great attraction [ ... ] going to a place and getting to know the winery or who is the winemaker, meeting the people is special."

(V18_Female, 32 years old)

The learning outcomes are, according to the visitors' perceptions, very much a result of this social interaction and of the different experiences they were involved in. 
They learnt about the diversity of wineries in Bairrada and their specificities, the high quality of the wine, the diversity of grape varieties of the region, wine production techniques, the authentic hospitality of Portuguese people and the changing landscape in the region. Some of the visitors pointed out the relevance of getting to know the history of the local producers and family businesses, the production techniques or the terroir features revealed in wine tastings during a cellar visit or a wine and food pairing experience. A US visitor pointed out these aspects:

"Their history and how they do it, they told us the whole history of the buildings and of the land and also what they are doing, how they are handling the grapes, what they put in it, for how long, everything, so, we know the hard work."

(V13_Male, 56 years old)

In food and wine pairing, visitors enhanced not only the quality of the regional products and their combination with the most appropriate wines, but also the possibility of learning about the cultural and historical features of the products they were experiencing. This learning process was stimulated by the staff, local producers or the winery owners, contributing to a genuine and unique experience. Visitors also showed enchantment regarding the communication established between them and the agents, reinforcing how special it was for them. In line with this, the importance of storytelling was clear in visitors' discourses, when referring to the historical and cultural elements added by this contact to the experience. Besides, the possibility of getting to know the historical features and the local production characteristics while tasting the local wines promoted a more authentic experience, where family historical features gave visitors the opportunity to better appreciate both the wine and the setting:

"As Americans, our history goes back not many generations. Today we talked about his family's winery [Luís Pato winemaker] and it being in the family's business for generations ... we don't have that, so it's really fascinating to us, this winery ... his great-great-great grandfather started."

(V14_Female, 54 years old)

\subsection{Word Cloud}

The word cloud presented in Figure 1 shows evidence of the most frequent words in visitors' interviews, reinforcing the main elements of the wine tourism experience in Bairrada. In the visitors' discourse, the word wine (vinho) was the most prominent, followed by experience (experiência), people (pessoas), Bairrada, food and gastronomy (comida e gastronomia), region (região), destination (destino), route (rota), think, roast suckling pig (leitão), wine tourism, wineries, vineyards, sparkling wine, wine tasting, thermae, bike, friends and harvesting. Besides wine, other elements that, combined with wine, contribute to the uniqueness of the experience were also pointed out, mainly in terms of gastronomy, the human interaction and the contact with the destination environment ('vineyards', 'bike' and 'harvesting'). 


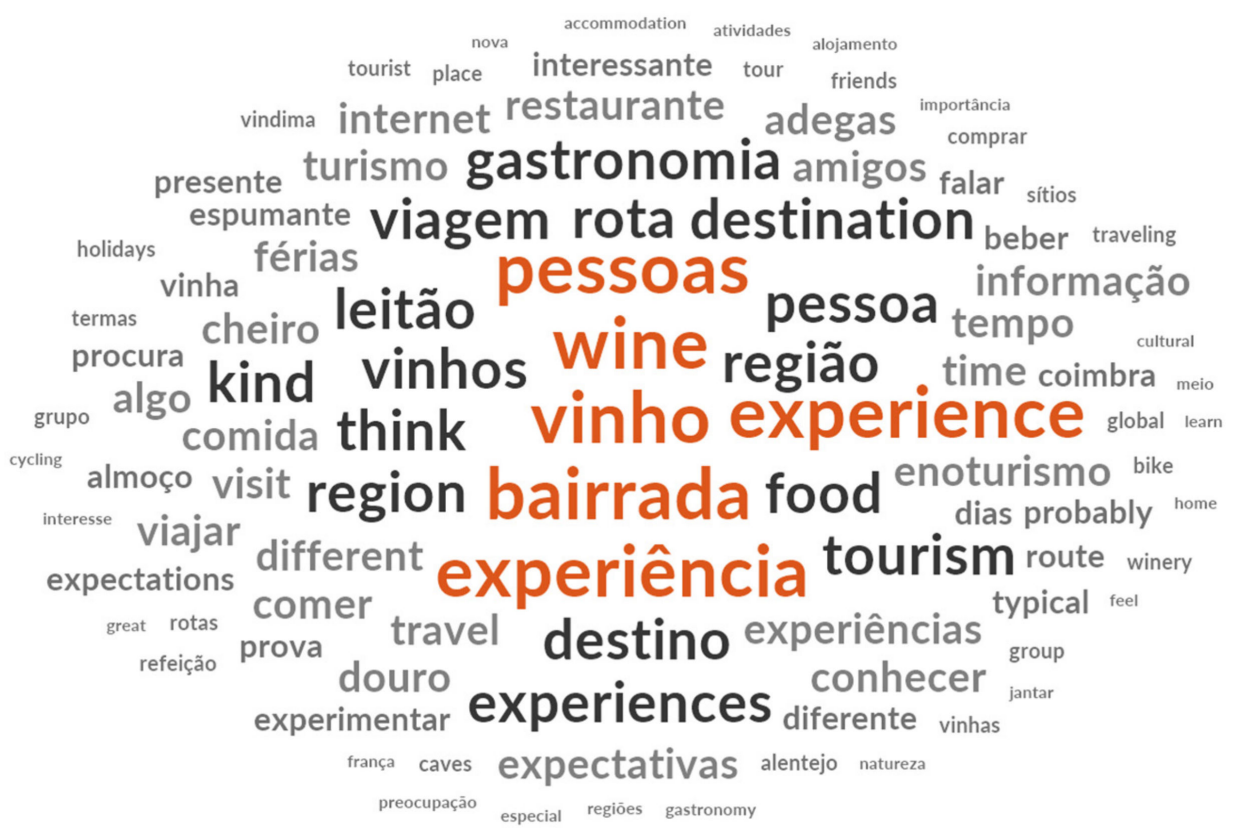

Figure 1. Word Cloud.

\section{Discussion and Conclusions}

This empirical study reflects on the importance of interaction (with the human and the physical experiencescape) in co-creative rural wine tourism and terroir experiences, enhancing value-creation through the integration of a multiplicity of resources $[2,36,50]$. Based on such special interest tourism, the results of this study may also contribute to reinforcing the need to implement rural destinations' strategies regarding their sustainable economic and social growth, as well as to reflect on tourism marketing strategies for these destinations.

For once, visitors and locals (winery staff, owners and local residents) integrate their own social and cultural resources while interacting in a (sometimes cross-cultural) encounter, sharing impressions, knowledge, experiences and developing, even if transitory and eventually superficial, relationships. Secondly, the territory's cultural and natural resources are also a central part of this co-creation, with traditions, local cuisine, wine landscapes and the natural surrounding not only serving as a stage for the experience, but rather being an essential ingredient, with elements visitors physically and actively engage with. As a distinctive and regional product, wine can contribute to fostering rural territories' economy, enhancing cultural and heritage local traits and promoting conscious sustainable practices that can add value to these territories and, consequently, to the related tourism experience [11].

Results also show that two segments of wine tourists may be distinguished: the first is a segment with more interest and knowledge about wine, corresponding to regular wine consumers, having already been in different wine contexts on holidays, being interested in learning about terroir characteristics and searching specifically for wine experiences. The second segment seems to be less focused on wine, enjoying this product during meals and not specifically in wineries and visits to cellars, while also enjoying the vineyardmarked landscapes. These findings confirm results of studies and reflections about the importance of distinguishing diverse profiles of wine destination visitors in order to correspondingly develop different experience settings and opportunities [2,3,5,10,23,32-34]. This is a relevant topic for wine producers and supply agents who are expected to facilitate diversified experiences, according to tourists' needs and preferences, thereby contributing to tourists' immersion in the experiencescape, and to foster interaction and engagement with the human and physical environment. 
Apart from the recognition of the presence and importance or not of primarily wine-interested visitors in wine destinations, findings also support the understanding of the importance of other local attractions and resources, not necessarily related to wine, for the destination experience of all tourists, including wine enthusiasts $[3-5,10,24,26]$. Furthermore, in the Bairrada region, the relevance of gastronomy, of rural and natural landscapes and social interaction with local people, as well as the possibility of learning about wine and its regional specificities, is very clear and is a result of tourists' engagement in several experiences and interaction with local actors and resources. This perspective corroborates the findings of a netnography study regarding the wine experience in this region [15]. Both segments demonstrated that the contact with local agents and with natural and cultural features is crucial during visitors' wine experiences, contributing to sensory stimulation and the unique traits of the experience, confirming the relevance of the winescape, already mentioned in previous studies [33,36]. Destinations' resources will contribute to tourists' immersion and memorability. Hence, destination stakeholders and supply agents should recognize the relevance of combining natural and cultural attractions with wine experiences, since visitors expressed their interest in this combined offer (e.g., tasting wine while appreciating the aesthetics of the landscape). The adoption of a holistic perspective may contribute to designing more enriching and unique co-creative wine experiences.

Bruwer et al. [24] stress the importance of diversifying the experiences offered beyond the cellar-doors. For food and wine pairing, the authors suggest that a network approach between wineries and local restaurants would enhance the region's attractiveness. This approach has already been implemented in Bairrada by one of the wineries, which visitors commented on positively in their interviews. Results showed that, for many, the blending of high-quality regional food products (delivered from a local restaurant) with wines from that cellar, combined with social interaction encouraged by the cellar owners' storytelling, presented the perfect elements that contributed to an exquisite, memorable and unique experience. All this also fostered visitors' willingness to buy wine at the end of the experience as a special souvenir that would extend the experience after the visit. Destination management organizations should thus consider networking between diverse regional wine- and non-wine-related actors and businesses as a relevant strategy to improve the tourist experience in the region and encourage revisiting [24].

According to study results, the wine owners' family history was part of the storytelling that was highly appreciated by visitors. This is in line with Frost et al.'s [33] (p. 6) findings that such family stories contribute to wine cellars' and regions' distinctiveness and competitive advantage of "fascinate[ing] people". The possibility of visitor contact with the owner was shown to be of great importance to active experience co-creation [53]. Visitors in Bairrada confirmed how extraordinary the experience was, due to the storytelling of the winemaker and owner of the winery, Luis Pato, who accompanied the visitors in wine and food pairing and wine tasting experiences. Engaging visitors in genuine experiences and facilitating the opportunity of shared value creation (between visitors and the winemaker) is a competitive advantage for destinations, enhancing satisfaction and loyalty $[53,54]$. As also mentioned by Ánton et al. [46] (p. 1420), social interaction with "experts is mainly valued", permitting unique learning opportunities.

Visitors' curiosity and interest in getting to know the history of the winery and of the owner's family in previous generations stood out in their discourses, allowing them to feel more engaged in the experience. In a very personalized way, visitors were invited to immerse themselves in the wine experience and its social, cultural and symbolic context, through diverse story elements leading to memorable co-creative experiences $[33,53]$. This highly appreciated cultural knowledge-transfer should be taken into account by wine producers when designing wine tourism experiences. Wine producers and other local agents may assume the role of the destination's cultural-brokers, since visitors feel more immersed and engaged in a personalized and close, 'authentic' story-telling context. These contexts are also facilitators of appealing experience co-creation scenarios. 
Our findings show that the stimulation of human interaction also has a positive impact on visitors' interaction with the physical environment [70] and that local resources contribute to deepening visitors' engagement in co-creative wine experiences, thus confirming several authors' findings $[4,30,39]$. The aesthetical dimension of Pine and Gilmore's model [18] also seemed to be enhanced, since natural elements of the wine landscape encouraged engaging experiences within the physical environment, as stressed by visitors. This confirms Thanh and Kirova's [71] findings, suggesting the importance of highlighting physical local resources as unique experience elements within the destination's experience marketing strategies [5,72], which may also contribute to social and economic development of rural wine destinations.

Study results also confirmed the relevance of the learning process in wine experiences $[1,10,30,31,71]$. Visitors to this wine region revealed the importance of learning about local culture and wine production techniques and processes, mostly resulting from staff and local producers' interaction in different experience contexts. Hence, local agents are crucial elements in shared value-creation: they act as cultural brokers $[16,17,40,44,45]$.

The hospitality of the local community and staff from wineries was also highly appreciated, contributing to experience satisfaction. The interaction between visitors, local producers, local staff or the owner of the winery is particularly special, with pleasurable experiences emerging from this contact [2]. One visitor pointed out the authenticity she felt in participating in the process of harvesting. As Antón et al. [46] suggest for rich, immersive museum experiences, active and interactive tourist participation seems to also be applicable to wine tourism experiences, with co-creative contexts allowing tourists deeper involvement with the visited place $[16,17,30,44,45,47]$. This perspective may be applied to the present study, where active participation was facilitated by diverse experiences, including wine tastings, food and wine pairings, harvesting and also exploring the natural aroma of the destination if cycling. However, visitors' perspectives were primarily enhanced by the combination of participation with human and physical environment interaction.

Considering the potential of wine-producing regions to promote diverse combined elements, a conceptual model is proposed (Figure 2), with a particular focus on interaction, due to the recognized relevance of this dimension within the scope of experience cocreation $[17,39,44,48]$. This conceptual model stresses the significant role of both the human and physical environments in wine experiences, based on the premise that these are the contexts where tourists assume an active and central part, not only while interacting with different destination stakeholders (e.g., wineries' staff, local producers), but also by immersing themselves in the destination setting (e.g., the vineyards landscape). Co-creative wine experiences give visitors the opportunity to develop their skills and deepen their knowledge ('operant resources'), including the wine-producing process, wine tasting, wine and food pairing, harvesting techniques, as well as to interact with the setting ('operand resources'), also perceived as winescape, and enjoy the aesthetics of its natural and cultural elements. The mingling of the operant and operand resources has the potential to promote the uniqueness and quality of the experience [36]. 


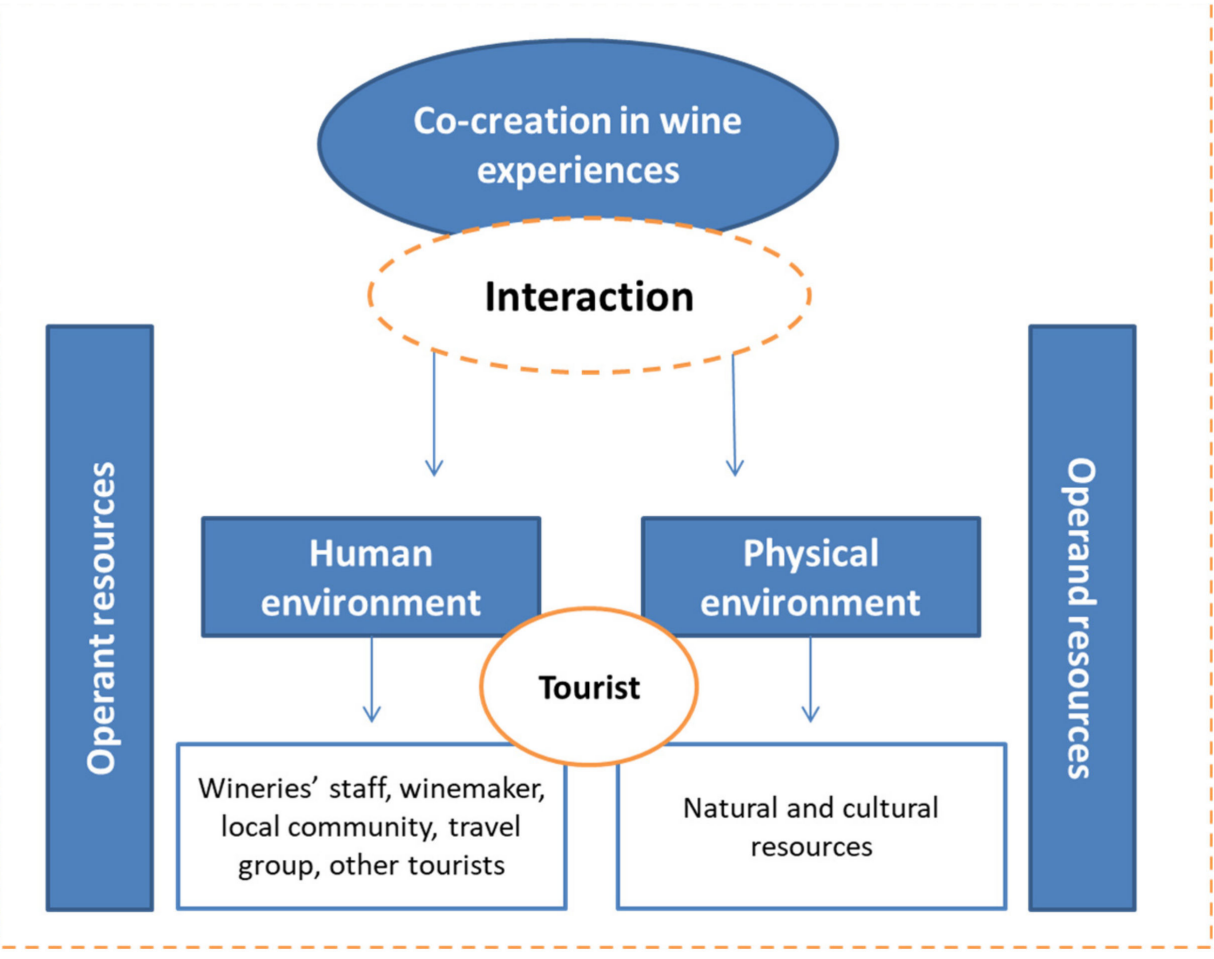

Figure 2. Conceptual model: Interaction as a key dimension in co-creation of wine experiences.

This study offers theoretical and managerial contributions to understanding the importance of interaction in co-creative wine and food experiences. The findings stress the importance of the destination managers' role as facilitators of engaging, memorable experiences, in which tourists assume a central role co-creating value with local agents and communities. Involving, interactive and immersive experiences seem to improve the tourist experience and contribute to tourists' satisfaction, potentially enhancing economic benefits of local agents and destinations' positioning and competitive advantage.

Interaction with both the human and physical experiencescape is a key dimension of co-creative wine and food experiences, creating deeper visitor engagement, stimulating learning and contributing to meaningful and immersive experiences that lead to increasing place attachment and visitors' loyalty. Hence, wine producers and destination stakeholders should carefully facilitate and design co-creation experiences as part of the management and marketing concept. Some limitations of the study need to be acknowledged. The visitor interviews were undertaken in the establishments of only a few regional supply agents, which may have conditioned responses, despite the general formulation of questions regarding their visit to the region and not the particular service context. Future research would benefit from including a more extended analysis, also considering other Portuguese wine regions, while validation and comparisons with other destinations could add to a deeper understanding of the role of particular context variables. Regarding methodology, although a qualitative study promotes an in-depth analysis, data analysis would benefit from a combination with a quantitative approach, which would require an extended sample to facilitate the identification of different visitor profiles, and any differences between them in terms of co-creative wine tourism experiences.

Author Contributions: Conceptualization, M.C., E.K. and M.J.C.; methodology, M.C., E.K. and M.J.C.; software, M.C.; validation, E.K. and M.J.C.; formal analysis, M.C., E.K. and M.J.C.; investigation, M.C., E.K. and M.J.C.; resources, M.C., E.K. and M.J.C.; data curation, M.C., E.K. and M.J.C.; writingoriginal draft preparation, M.C., E.K. and M.J.C.; writing-review and editing, M.C., E.K. and M.J.C.; supervision, E.K. and M.J.C.; project administration and funding acquisition, E.K. and M.J.C. All authors have read and agreed to the published version of the manuscript. 
Funding: This work was financially supported by the project TWINE-PTDC/GES-GCE/32259/2017 -POCI-01-0145-FEDER-032259, funded by FEDER, through COMPETE 2020-Operational Program Competitiveness and Internationalization (POCI) and by national funds (OPTDC/GES-GCE/32259/ 2017-E), through FCT/MCTES.

Data Availability Statement: Data are not publicly available.

Conflicts of Interest: The authors declare no conflict of interest.

\section{Appendix A}

Questions in the semi-structured interview:

- What do you expect to experience in these destinations?

- What do you consider most typical of this Region?

- Given the experience on the Bairrada Route, how would you describe it?

- What activities did you engage in and which places did you visit?

- What did you learn?

- In what way were your senses stimulated?

- How do you characterize the contact you had with other people (staff, residents, other tourists) during the experience?

\section{References}

1. Brochado, A.; Stoleriu, O.; Lupu, C. Wine tourism: A multisensory experience. Curr. Issues Tour. 2021, 24, 597-615. [CrossRef]

2. Bruwer, J.; Alant, K. The hedonic nature of wine tourism consumption: An experiential view. Int. J. Wine Bus. Res. 2009, 21, 235-257. [CrossRef]

3. Charters, S.; Ali-Knight, J. Who is the wine tourist? Tour. Manag. 2002, 23, 311-319. [CrossRef]

4. Cohen, E.; Ben-Nun, L. The important dimensions of wine tourism experience from potential visitors' perception. Tour. Hosp. Res. 2009, 9, 20-31. [CrossRef]

5. Carmichael, B. Understanding the wine tourism experience for winery visitors in the Niagara region. Tour. Geogr. 2005, 7, 185-204. [CrossRef]

6. Getz, D.; Brown, G. Critical success factors for wine tourism regions: A demand analysis. Tour. Manag. 2006, 27, 146-158. [CrossRef]

7. Kruger, M.; Vilijoen, A. Terroir wine festival visitors: Uncorking the origin of behavioural intentions. Curr. Issues Tour. 2019, 24, 616-636. [CrossRef]

8. Cunha, D.; Carneiro, M.J.; Kastenholz, E. "Velho Mundo" versus “Novo Mundo": Diferentes perfis e comportamento de viagem do enoturista? Rev. Tur. Desenvolv. 2020, 34, 113-128.

9. Kastenholz, E.; Carneiro, M.J. O potencial do enoturismo em áreas rurais: Perspetivas do projeto TWINE. In Proceedings of the III Encuentro Iberoamericano de Turismo Rural, Évora, Portugal, 29 October 2018.

10. Dodd, T. Opportunities and pitfalls of tourism in a developing wine industry. Int. J. Wine Mark. 1995, 7, 5-16. [CrossRef]

11. Vázquez Vicente, G.; Martín Barroso, V.; Blanco Jiménez, F.J. Sustainable Tourism, Economic Growth and Employment-The Case of the Wine Routes of Spain. Sustainability 2021, 13, 7164. [CrossRef]

12. Holland, T.; Smit, B.; Jones, G. Toward a conceptual framework of terroir tourism: A case study of the Prince Edward county, Ontario wine region. Tour. Plan. Dev. 2014, 11, 275-291. [CrossRef]

13. Kastenholz, E.; Marques, C.P.; Carneiro, M.J. Place attachment through sensory-rich, emotion-generating place experiences in rural tourism. J. Destin. Mark. Manag. 2020, 17, 100455, ISSN 2212-57. [CrossRef]

14. Garibaldi, R.; Stone, M.; Wolf, E.; Pozzi, A. Wine travel in the United States: A profile of wine travellers and wine tours. Tour. Manag. Perspect 2017, 23, 53-57. [CrossRef]

15. Kastenholz, E.; Cunha, D.; Eletxigerra, A.; Carvalho, M.; Silva, I. Exploring Wine Terroir Experiences: A Social Media Analysis. In Advances in Tourism, Technology and Systems; ICOTTS 2020. Smart Innovation, Systems and Technologies; Abreu, D., Liberato, E.A., González, J.C., Ojeda, G., Eds.; Springer: Singapore, 2021; Volume 209, pp. 401-420.

16. Binkhorst, E.; Dekker, T.D. Agenda for co-creation tourism experience research. J. Hosp. Mark. Manag. 2009, 18, 311-327. [CrossRef]

17. Campos, A.; Mendes, J.; do Valle, P.; Scott, N. Co-creation experiences: Attention and memorability. J. Travel Tour. Mark. 2016, 33, 1309-1336. [CrossRef]

18. Pine, B.; Gilmore, J. Welcome to the experience economy. Harv. Bus. Rev. 1998, 76, 97-105.

19. Carvalho, M.; Kastenholz, E.; Carneiro, M.J. Co-creation experiences. In Encyclopedia of Tourism Management and Marketing; Buhalis, D., Ed.; Edward Elgar Publishing Limited: Cheltenham, UK, 2021. [CrossRef]

20. Richards, G. Creativity and tourism: The state of the art. Ann. Tour. Res. 2011, 38, 1225-1253. [CrossRef] 
21. Rachão, S.; Breda, Z.; Fernandes, C.; Joukes, V. Drivers of experience co-creation in food-and-wine tourism: An exploratory quantitative analysis. Tour. Manag. Perspect. 2021, 37, 100783. [CrossRef]

22. Sharpley, R. Flagship attractions and sustainable rural tourism development: The case of the alnwick garden. England. J. Sustain. Tour. 2007, 15, 125-143. [CrossRef]

23. Hall, C.M.; Sharples, E.; Cambourne, B.; Macionis, N. Wine Tourism around the World: Development, Management and Markets; Butterworth-Heinemann: Auckland, New Zealand, 2000.

24. Bruwer, J.; Prayag, G.; Disegna, M. Why wine tourists visit cellar doors: Segmenting motivation and destination image. Int. J. Tour. Res. 2017, 20, 355-366. [CrossRef]

25. Carvalho, M.; Kastenholz, E.; Carneiro, M.J. A co-criação de experiências enogastronómicas: O caso da rota da Bairrada. J. Tour. Dev. 2021, 36, 325-339.

26. Novo, G.; Osorio, M.; Sotomayor, S. Wine tourism in Mexico: An initial exploration. Anatolia 2019, 30, 246-257. [CrossRef]

27. Robinson, R.; Getz, D. Profiling potential food tourists: An Australian study. Br. Food J. 2014, 116, 690-706. [CrossRef]

28. Strickland, P.; Laing, J.; Frost, W.; Williams, K. Trends in experience design-Strategies for attracting millennials to wineries in Victoria, Australia. In The Routledge Handbook of Tourism Experience Management and Marketing; Dixit, S.K., Ed.; Routledge: London, UK, 2020; pp. 207-217.

29. Malerba, R.; Kastenholz, E.; Carneiro, M.J. Family-friendly tourism supply. In Encyclopedia of Tourism Management and Marketing; Buhalis, D., Ed.; Edward Elgar Publishing Limited: Cheltenham, UK, 2021. [CrossRef]

30. Gu, Q.; Wiu, H.; King, B.; Huang, S. Understanding the wine tourism experience: The roles of facilitators, constraints, and involvement. J. Vacat. Mark. 2020, 26, 211-229. [CrossRef]

31. Quadri-Felitti, D.; Fiore, A.M. Destination loyalty: Effects of wine tourists' experiences, memories, and satisfaction on intentions. Tour. Hosp. Res. 2013, 13, 47-62. [CrossRef]

32. Back, R.; Lowry, L.; Higgins, L. Exploring a wine farm micro-cluster: A novel business model of diversified ownership. J. Vacat. Mark. 2021, 27, 103-116. [CrossRef]

33. Frost, W.; Frost, J.; Strickland, P.; Maguire, J. Seeking a competitive advantage in wine tourism: Heritage and storytelling at the cellar-door. Int. J. Hosp. Manag. 2020, 87. [CrossRef]

34. Santos, V.; Ramos, P.; Almeida, N.; Santos-Pavón, E. Wine and wine tourism experience: A theoretical and conceptual review. Worldw. Hosp. Tour. Themes 2019, 11, 718-730. [CrossRef]

35. Hall, C.M. Wine tourism in New Zealand. In Tourism Down under II: Towards a More Sustainable Tourism; Kearsley, G., Ed.; Centre for Tourism, University of Otago: Dunedin, New Zealand, 1996; pp. 109-119.

36. Johnson, R.; Bruwer, J. Regional Brand image and perceived wine quality: The consumer perspective. Int. J. Wine Bus. Res. 2007, 19, 276-297. [CrossRef]

37. Mathis, E.; Kim, H.; Uysal, M.; Sirgy, J.; Prebensen, N. The effect of co-creation experience on outcome variable. Ann. Tour. Res. 2016, 57, 62-75. [CrossRef]

38. Prahalad, C.; Ramaswamy, V. Co-creation experiences: The next practice in value creation. J. Interact. Mark. 2004, 18, 5-14. [CrossRef]

39. Minkiewicz, J.; Evans, J.; Bridson, K. How do consumers co-create their experiences? An exploration in the heritage sector. J. Mark. Manag. 2014, 30, 30-59. [CrossRef]

40. Prebensen, N.; Vittersø, J.; Dahl, T. Value co-creation significance of tourist resources. Ann. Tour. Res. 2013, 42, 240-261. [CrossRef]

41. Rihova, I.; Buhalis, D.; Moital, M.; Gouthro, M. Conceptualizing customer-to-customer value co-creation in tourism. Int. J. Tour. Res. 2015, 17, 356-363. [CrossRef]

42. Gummesson, E.; Mele, C. Marketing as value co-creation through network interaction and resource integration. J. Bus. Mark. Manag. 2010, 4, 181-198. [CrossRef]

43. Vargo, S.L.; Lusch, R. Evolving to a New Dominant Logic for Marketing. J. Mark. 2004, 68, 1-17. [CrossRef]

44. Carvalho, M.; Lima, J.; Kastenholz, E.; Sousa, A. Co-creative rural tourism experiences: Connecting tourists, community and local resources. In Meeting Challenges for Rural Tourism through Co-Creation of Sustainable Tourist Experiences; Kastenholz, E., Carneiro, M.J., Eusébio, C., Figueiredo, E., Eds.; Cambridge Scholars Publishing: Newcastle upon Tyne, UK, 2016 ; pp. 79-101.

45. Kastenholz, E.; Carneiro, M.J.; Marques, C.P.; Lima, J. Understanding and managing the rural tourism experience: The case of a historical village in Portugal. Tour. Manag. Perspect. 2012, 4, 207-214. [CrossRef]

46. Antón, C.; Camarero, C.; Garrido, M.J. Exploring the experience value of museum visitors as a co-creation process. Curr. Issues Tour. 2018, 21, 1406-1425. [CrossRef]

47. Huang, S.; Choi, H.-S. Developing and validating a multidimensional tourist engagement scale (TES). Serv. Ind. J. 2019, 39, 469-497. [CrossRef]

48. Buonincontri, P.; Morvillo, A.; Okumus, F.; van Niekerk, M. Managing the experience co-creation process in tourism destinations: Empirical findings from Naples. Tour. Manag. 2017, 62, 264-277. [CrossRef]

49. McCartney, G.; Chen, Y. Co-Creation Tourism in an Ancient Chinese Town. J. China Tour. Res. 2019, 16, 159-182. [CrossRef]

50. Wei, M.; Bai, C.; Li, C.; Wang, H. The effect of host-guest interaction in tourist co-creation in public services: Evidence from Hangzhou. Asia Pac. J. Tour. Res. 2020, 25, 457-472. [CrossRef]

51. Kastenholz, E.; Carneiro, M.J.; Eusébio, C. Diverse socializing patterns in rural tourist experiences-a segmentation analysis. Curr. Issues Tour. 2018, 21, 401-421. [CrossRef] 
52. Santos, V.; Ramos, P.; Almeida, N.; Marôco, J.; Santos-Pavón, E. Wine tourist profiling in the Porto wine cellars: Segmentation based on wine product involvement. Anatolia 2020, 31, 577-590. [CrossRef]

53. Jollife, L.; Piboonrungroj, P. The role of themes and stories in tourism experiences. In The Routledge Handbook of Tourism Experience Management and Marketing; Dixit, S.K., Ed.; Routledge: London, UK, 2020; pp. 218-228.

54. Mossberg, L. Extraordinary Experiences through Storytelling. Scand. J. Hosp. Tour. 2008, 8, 195-210. [CrossRef]

55. Liberato, D.; Nunes, M.; Liberato, P. Wine and Food Tourism Gamification. Exploratory Study in Peso da Régua. In Advances in Tourism, Technology and Systems; ICOTTS 2020. Smart Innovation, Systems and Technologies; Abreu, D., Liberato, E.A., González, J.C., Ojeda, G., Eds.; Springer: Singapore, 2021; Volume 208, pp. 497-508. [CrossRef]

56. Martin, D.; Woodside, A. Storytelling research on international visitors Interpreting own experiences in Tokyo. Qual. Mark. Res. Int. J. 2011, 14, 27-54. [CrossRef]

57. Moina, S.; Hosanyb, S.; O’Brien, J. Storytelling in destination brands' promotional videos. Tour. Manag. Perspect. 2020, 34. [CrossRef]

58. Prebensen, N.; Foss, L. Coping and Co-creating in Tourist Experiences. Int. J. Tour. Res. 2011, 13, 54-67. [CrossRef]

59. Rota da Bairrada. Quem Somos. Available online: http://www.rotadabairrada.pt / quemsomos / ?id=3\&title=quem-somos\& idioma $=$ pt (accessed on 2 July 2021).

60. Infovini. O portal do vinho Português. Available online: https://infovini.pt (accessed on 2 July 2021).

61. Pordata. Base de Dados Portugal Contemporâneo. 2021. Available online: https://www.pordata.pt/Municipios/Capacidade+ nos+alojamentos+tur\%c3\%adsticos+total+e+por+tipo+de+alojamento-747 (accessed on 30 July 2021).

62. Pordata. Base de dados Portugal Contemporâneo. 2019. Available online: https://www.pordata.pt/Municipios/Dormidas+nos+ alojamentos+tur\%c3\%adsticos+por+100+habitantes-761 (accessed on 30 July 2021).

63. Centre of Portugal. Mata do Buçaco. 2021. Available online: https://www.centerofportugal.com/pt/poi/a-mata-do-bucaco/ (accessed on 30 July 2021).

64. Yin, R. Qualitative Research from Start to Finish; The Guildford Press: New York, NY, USA, 2011.

65. Creswell, J. Educational Research: Planning, Conducting and Evaluating Quantitative and Qualitative Research, 4th ed.; Pearson Education: Boston, MA, USA, 2012.

66. Fraenkel, J.; Wallen, N.; Hyun, H. How to Design and Evaluate Research in Education, 8th ed.; McGraw Hill: New York, NY, USA, 2012.

67. Fusch, P.; Ness, L. Are We There Yet? Data Saturation in Qualitative Research. Qual. Rep. 2015, 20, 1408-1416.

68. Patton, M. Qualitative Research \& Evolution Methods; Sage Publications: Thousand Oaks, CA, USA, 2002.

69. Martinho, V. Contributions from Literature for Understanding Wine Marketing. Sustainability 2021, 13, 7468. [CrossRef]

70. Arnould, E.; Price, L. River Magic: Extraordinary Experience and the Extended Service Encounter. J. Consum. Res. 1993, 20, 24-45. [CrossRef]

71. Thanh, T.; Kirova, V. Wine tourism experience: A netnography study. J. Bus. Res. 2018, 83, 30-37. [CrossRef]

72. Carneiro, M.J.; Lima, J.; Silva, A. Landscape and the rural tourism experience: Identifying key elements, addressing potential, and implications for the future. J. Sustain. Tour. 2015, 23, 1217-1235. [CrossRef] 